\title{
Revistas cientificas brasileiras. Publicar e perecer?
}

\section{Brazilian scientific journals. Publish and perish?}

O crescimento da produção do conhecimento científico no mundo é um fenômeno bem conhecido. Evidentemente esta alta produção torna-se irrelevante se não for acompanhada de sua divulgação com fidedignidade e qualidade, o que exige, como condição sine qua non, que os veículos de divulgação tenham características técnico-científicas mínimas, a fim de oferecerem as informações necessárias para uso no processo de desenvolvimento de qualquer país. Ademais a disseminação da informação científica deve ser feita na quantidade correspondente ao que foi produzido em termos de conhecimento e inovação. De posse desses elementos, os tomadores de decisão em qualquer nível, público ou privado, terão os meios necessários para a promoção de políticas e gestões adequadas aos seus programas de trabalho. Como mostrado por Alvin Toffler nos seus dois livros A Terceira Onda e Power Shift, o aumento do conhecimento e, especialmente, o crescimento técnicocientífico, representa aumento de poder.

Nesse contexto o Brasil tem demonstrado, nos últimos 30 anos, um ritmo acelerado, o que pode ser verificado pelo aumento de suas publicações científicas indexadas no sistema ISI -Thomson Reuters, a mais respeitada base bibliográfica mundial. Com $2 \%$ da produção de artigos científicos em revistas com fator de impacto, o país ultrapassou todos os seus concorrentes latino-americanos e mesmo alguns países europeus.

Entretanto, dois aspectos ainda são críticos. Um deles é que paises em desenvolvimento como a Coréia e a China têm ritmo de publicação ainda mais acelerado; o outro, muito mais sério, é que, embora o Brasil tenha avançado na quantidade de artigos publicados em periódicos de grande renome, poucos destes são editados no país. De fato, a visibilidade internacional das revistas científicas publicadas no Brasil é ainda muito pequena. Embora no nosso país sejam editados cerca de 3.000 periódicos, menos de um décimo destes estão indexados na base ibero-latino americana SciELO. Em bases de grande representação mundial, como ISI e o Pubmed, menos ainda. Além disso, não chega a uma dezena o número de revistas brasileiras que ultrapassam atualmente uma unidade no fator de impacto, medido pelo ISI.

É importante reconhecer que os órgãos patrocinadores e gestores da pesquisa cientifica no Brasil, como o CNPq e a CAPES, têm investido fortemente em programas destinados à sua melhoria, o que muito tem contribuído, ao lado do esforço dos editores, para a continuidade e a inserção mundial de vários dos nossos periódicos. Não é sem razão que a CAPES está procurando implantar várias e diferenciadas alterações no seu sistema Qualis, o que significa maiores exigências para os cursos de pós-graduação, sabidamente a fonte da quase totalidade da produção científica do país. Os aspectos positivos dessas alterações são óbvios, pois os programas, dentro da lógica do Publicar ou Perecer, procurarão aumentar as suas publicações em revistas de maior impacto, que são, na maioria, produzidos no exterior. Isto favorecerá, certamente, uma maior visibilidade da ciência produzida no Brasil, o que é muito bom.

Mas aqueles programas cuja produção científica, devido a sua natureza e escopo, só possa ser veiculada em periódicos, que mesmo qualificados tenham menores índices de impacto, serão penalizados conforme os conceitos atribuídos pela CAPES. Ou seja, ainda que divulgando conhecimentos científicos relevantes para o país em revistas brasileiras bem qualificadas, poderão ser rebaixados naquele conceito. Isto que dizer, em outras palavras, o surgimento de uma outra lógica, que para muitos cursos de pós-graduação, corresponde, não a Publicar ou Perecer, mas a Publicar e Perecer. Podemos considerar, entretanto, que, embora este seja um triste panorama para nossa Pós-Graduação em muitas áreas, não deixa de ser também um estimulo e um desafio para que ela produza pesquisas de melhor nível e para que os periódicos brasileiros busquem uma maior integração ao cenário da editoração científica mundial. Para estes a busca de uma excelência qualitativa, aliás um constante desafio de qualquer editor, torna-se ainda mais premente. E salutar, pois todos precisarão aumentar as suas exigências editoriais a fim de alcançarem mais altos padrões técnicos e científicos.

O grande historiador inglês Arnold Toynbee, ao desenvolver a sua teoria do Desafio-Resposta (vide "Um Estudo de Historia") para interpretação da historia universal, propõe que a sobrevivência de uma comunidade, sociedade ou civilização depende da forma e dos meios que elas utilizam para fazer frente as dificuldades dos momentos críticos. 
Não é razoável publicar e perecer.

Como comunidade cientifica, no presente contexto, cabe portanto respondermos ponderadamente e da maneira certa ao presente desafio.

José Eulálio Cabral-Filho

Editor Executivo da Revista Brasileira de Saúde Materno Infantil 